\title{
KRISTALINITAS MEMBRAN HIBRID POLISULFON-LEMPUNG PADA MEDIA KOAGULASI AIR DAN CAMPURAN AIR-2PROPANOL
}

\author{
Zaiyar \\ Sekolah Tinggi Teknologi Pekanbaru \\ Jalan: Dirgantara No. 4 Arengka Pekanbaru-Riau 28294
}

\begin{abstract}
ABSTRAK
Kristalinitas membran hibrid polisulfon-lempung dalam larutan casting yang dikoagulasikan dalam media koagulasi air dan campuran air-2 propanol menunjukkan hasil yang berbeda. Pengukluran dilakukan menggunakan menggunakan difraktometer sinar-X Schimizu Maxima 7000 pada sudut hamburan (20) $5^{\circ}-35^{\circ}$, dengan ukuran sampling puncak $0.02^{\circ}$ dan kecepatan pengamatan (scan) $2 \%$ menit. Derajat kristalinitas membran A (koagulan air) adalah sebesar 63,1185, sedangkan membran B (media koagulasi campuran air-2propanol adalah $31,7691$. Perbedaan derajat kristalinitas ini disebabkan pengaruh halangan sterik dari media koagulasi dan kecepatan difusi pertukaran antara pelarut dan non pelarut pada proses koagulasi pembentukan membran.
\end{abstract}

Kata Kunci: Kristalinitas, casting, media koagulasi, derajat kristalinitas

\section{PENDAHULUAN}

Pembentukan membran dalam bak koagulasi non pelarut disebabkan ketidaklarutan polimer pada non pelarut. Pembentukan membran terjadi dalam 2 tahap, yaitu: Tahap 1 adalah difusi non pelarut dan difusi pelarut keluar lapisan film membran polimer sehingga terbentuk cikal bakal membran berupa lapisan berpori di bawah lapisan tipis. Tahap 2 adalah penghilangan non pelarut dan terbentuknya membran.

Proses inversi fase pembentukan membran sangat dipengaruhi oleh parameter kinetik yaitu, pertukaran pelarut dan non pelarut selama proses koagulasi. Jika difusi non pelarut ke dalam larutan tuang lebih cepat dibandingkan difusi pelarut ke luar, maka menghasilkan lapisan yang berpori. Sebaliknya, jika difusi non pelarut lebih lambat dibandingkan difusi pelarut keluar maka terbentuk membran dengan lapisan yang rapat (Young \& Leo, 1996), yang secara tidak langsung akan mempengaruhi kristalinitas dari membran yang dihasilkan.

Kristalinitas merupakan salah satu sifat fisik material yang penting, karena mempengaruhi sifat lainnya seperti ketahanan termal dan mekanik (Kohan, 1973). Kristalinitas menunjukkan ikatan antara rantai-rantai molekul dalam material. Material yang mempunyai kristalinitas tinggi akan mempunyai susunan molekul yang teratur, sebaliknya molekul yang tidak teratur mempunyai kristalinitas rendah.

Kristalinitas membran dinyatakan dengan derajat kristalinitas. Penentuan derajat kristalinitas berdasarkan perbandingan antara daerah kristalin dan daerah kristalin + daerah amorf. Daerah kristalin menghasilkan puncak difraksi tajam dan daerah amorf akan memberikan puncak yang lebar pada pola difraksi sinar-X seperti ditunjukkan pada Gambar 1.

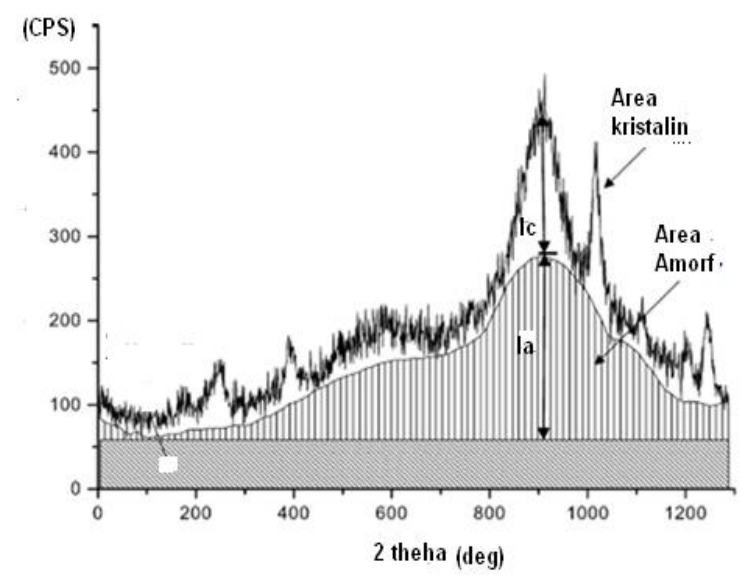

Gambar 1. Derajat Kristalinitas Membran dengan XRD (Sumber: Rabek 1980)

Derajat kristalinitas membran hibrid dihitung menggunakan persamaan 1

$$
X c=\frac{I c}{I a+I c} x 100 \% \ldots \ldots \ldots
$$

Dalam hal ini, $\mathrm{X}_{\mathrm{c}}$ adalah derajat kristalinitas $(\%), I_{c}$ adalah luas area kristalin dan $I_{a}$ adalah luas area amorf.

Metode difraksi sinar-X merupakan metode yang digunakan untuk menentukan derajat kristalinitas. Metode ini didasarkan pada interaksi antara materi dengan radiasi sinar elektromagnetik sinar-X (Dann, 2000), yang 
digunakan untuk mempelajari struktur kristal hingga tingkat atomik. Hal ini disebabkan setiap kristal memiliki jarak antar atom atau jarak bidang kristal yang berukuran hampir sama dengan panjang gelombang $(\lambda)$ sinar $X$.

\section{METODOLOGI PENELITIAN}

Pembuatan membran hibrid polisulfonlempung

Membran hibrid polisulfon-lempung yang dibuat hanya 1 (satu) jenis tetapi media koagulasi yang digunakan air dan. campuran non pelarut 2-propanol-air perbandingan (1:1). Membran dibuat dengan cara: melarutkan $18 \%$ polisulfon dalam $64 \%$ dimetil formamida (DMAc), zat aditif 9\% lempung, dan 9\% polietilen glikol.(PEG). Proses pelarutan dilakukan pada temperatur kamar selama 15 jam menggunakan pengaduk magnetik sampai larutan homogen. Larutan ini, disebut larutan tuang polimer.

Larutan tuang polimer didiamkan selama 3 jam untuk menghilangkan gelembung udara yang terperangkap di dalam larutan sebelum dilakukan pencetakan (Tweddle et al., 1994). Larutan tuang polimer selanjutnya ditebar di atas plat kaca yang telah diolesi aseton lalu diratakan dengan batang stainless steel hingga terbentuk lapisan tipis dan dibiarkan selama 5 menit. Kemudian lapisan tipis pada pelat kaca ini, ada yang direndam dalam bak koagulasi yang telah berisi air dan ada yang direndam campuran non pelarut 2-propanol-air perbandingan (1:1). Masing-masing proses koagulasi dilakukan selama 5 menit sehingga membran terkoagulasi. Membran hibrid polisulfon-lempung yang terkoagulasi dalam air diberi simbol PEL A dan PEL B

\section{Karakterisasi Kristalinitas Membran}

\section{Hibrid Polisulfon-Lempung}

Karakterisasi kristalinitas membran hibrid polisulfon-lempung PEL A dan PEL B dilakukan menggunakan difraksi sinar-X (XRD) yang bertujuan untuk mengidentifikasi lempung dan karakterisasi kristalinitas. Analisis dilakukan menggunakan difraktometer sinar-X Schimizu Maxima 7000 pada sudut hamburan (20) $5^{\circ}-35^{\circ}$, dengan ukuran sampling puncak $0.02^{\circ}$ dan kecepatan pengamatan (scan) $2 \%$ menit. Area kristalin dalam difraktogram XRD menghasilkan puncak tajam, sedangkan area amorf menghasilkan puncak lebar. Derajat kristalinitas dihitung menggunakan persamaan (1). Pengukuran kristalinitas membran dilakukan di Pusat Penelitian dan Pengembangan Keteknikan Kehutanan dan Pengolahan Hasil Hutan Bogor.

\section{HASIL DAN PEMBAHASAN}

Hasil karakterisasi kristalinitas membran hibrid polisulfon-lempung (PEL A dan PEL B) menggunakan XRD. ditunjukkan pada Gambar 1 dan 2. Derajat kristalinitasnya dicantumkan pada Tabel 1

Tabel 1. Derajat Kristalinitas Membran $\left(\right.$ Radiasi $\mathrm{Cu} \mathrm{K} \alpha, \mathrm{v}$ scan $=2^{\circ} /$ menit, $2 \theta=5-35^{\circ}$, $\mathrm{V}=40 \mathrm{kV}, \mathrm{I}=30 \mathrm{~mA}$ )

\begin{tabular}{llll}
\hline Membran & $\mathrm{I}_{\mathrm{a}}$ & $\mathrm{I}_{\mathrm{c}}$ & $\mathrm{X}_{\mathrm{c}}, \%$ \\
\hline PEL A & 0,7744 & 1,3253 & 63,1185 \\
& & & \\
PEL B & 0,9267 & 0,4315 & 31,7691 \\
\hline
\end{tabular}

Berdasarkan Difraktogram membran PEL A dan PEL B (Gambar 2 dan 3), diketahui bahwa kedua jenis membran hibrid mempunyai komposisi lempung sama yang terdiri dari: kaolin, muskovit dan kuarsa. Meskipun intensitas puncaknya Intensitas puncak difraktogram membran PEL A lebih rendah dibandingkan membran PEL B, tetapi luasan daerah amorf membran B lebih banyak dibandingkan membran PEL A. Akibatnya kedua membran mempunyai derajat kristaliniats yang berbeda.

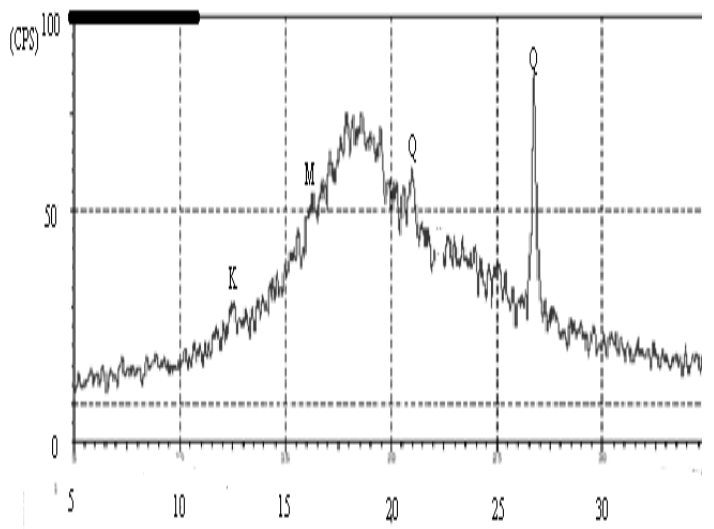

Gambar 2. Difraktogram Membran PEL A $\mathrm{K}=$ Kaolin $\mathrm{M}=$ Muskovit $\mathrm{Q}=$ Kuarsa 


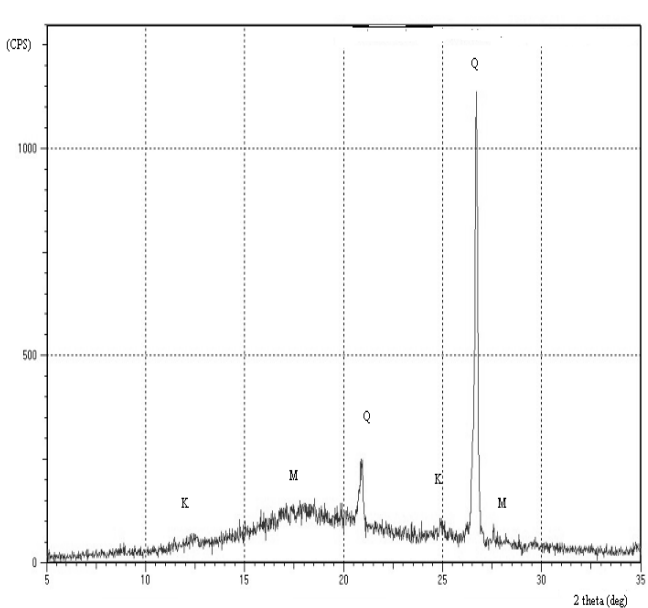

Gambar 3. Difraktogram Membran PEL B $\mathrm{K}=$ Kaolin, $\mathrm{M}=$ Muskovit. $\mathrm{Q}=$ Kuarsa

Derajat kristalinitas membran PEL A $(63,1185 \%)$ yang menunjukkan angka yang lebih tinggi dibandingkan membran PEL B $(31,7691 \%)$. Hal ini disebabkan kedua membran di koagulasi dalam media koagulasi yang berbeda. Meda koagulasi 2-propanol-air menyebabkan terjadinya penataan ulang struktur polimer ke arah tidak teratur (daerah amorf), akibatnya derajat kristalinitasnya.

Dalam pembentukan membran, karakteristik dari fase yang bertukar yaitu pelarut dan non pelarut selama proses koagulasi akan menentukan kecepatan difusi antara keduanya di dalam larutan polimer. Jika difusi non pelarut ke dalam larutan tuang lebih cepat dibandingkan difusi pelarut ke luar, maka menghasilkan lapisan yang berpori. Sebaliknya, jika difusi non pelarut lebih lambat dibandingkan difusi pelarut keluar maka terbentuk membran dengan lapisan yang rapat (Young et al., 1996).

Koefisien difusi non pelarut juga akan mempengaruhi kecepatan pertukaran pelarut dan non pelarut. Koefisien difusi non pelarut air lebih tinggi dibandingkan koefisien difusi non pelarut campuran 2-propanol-air. pada proses koagulasi.Oleh karena kecepatan pertukaran pelarut dan non pelarut pada penggunaan non pelarut air lebih cepat dibandingkan penggunaan non pelarut campuran 2-propanol-air.

Kekuatan ikatan dan faktor sterik juga akan mempengaruhi kecepatan pertukaran antara pelarut dan non pelarut. Berdasarkan struktur molekulnya, polisulfon mengandung gugus polar (gugus sulfon dan alkoksi).

Menurut Cifriadi et al., (2005), akan terjadi interaksi antara molekul non pelarut 2-propanolair dengan polisulfon melalui interaksi dipoldipol dan ikatan hidrogen, seperti ditunjukkan pada Gambar 4. Namun kekuatan ikatan hidrogen antara molekul 2-propanol-air pada gugus sulfon dan alkoksi lebih lemah dibandingkan ikatan hidrogen dengan non pelarut. 2-propanol-air. Hal ini disebabkan pengaruh dari 2 atom oksigen yang berdekatan sehingga ikatan ini tidak mempunyai perbedaan momen dipol yang menunjukkan lemahnya ikatan hidrogen yang terjadi. Kondisi ini menyebabkan derajat kristalinitas membran hibrid polisulfon-lempung PEL B lebih rendah dibandingkan membran PEL A yang menggunakan air sebagai non pelarut.

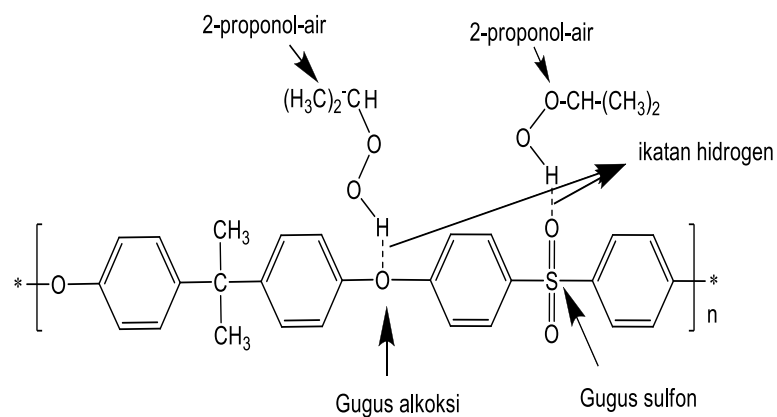

Gambar 4. Ikatan Hidrogen antara Polisulfon dan 2-Propanol-Air

Karakteristik dari pelarut dan non pelarut yang bertukar menentukan kecepatan difusi antara keduanya di dalam larutan casting. Hal ini akan mempengaruhi keteraturan ikatan yang dihasilkan. Karakteristik ini bisa juga dilihat dari faktor sterik maupun sifat pelarut dan non pelarutnya (Young et al, 1996).

Faktor sterik dilihat berdasarkan ukuran dan bentuk molekul. Berdasarkan strukturnya, polisulfon, memiliki ukuran yang paling besar diikuti oleh DMAc dan air sehingga mekanisme difusi yang terjadi dapat dijelaskan pada Gambar 5. Difusi non pelarut (air) ke dalam larutan casting lebih cepat dibandingkan difusi pelarut (DMAc) keluar (Gambar 5.b) maka menghasilkan struktur yang lebih teratur karena jarak antara molekul polisulfon meningkat. 
Sebaliknya, difusi non pelarut 2-propanol-air lebih lambat dibandingkan difusi pelarut keluar (Gambar 5c) maka terbentuk membran dengan struktur yang rapat (dense) karena jarak antaramolekul polisulfon menurun.

(b)

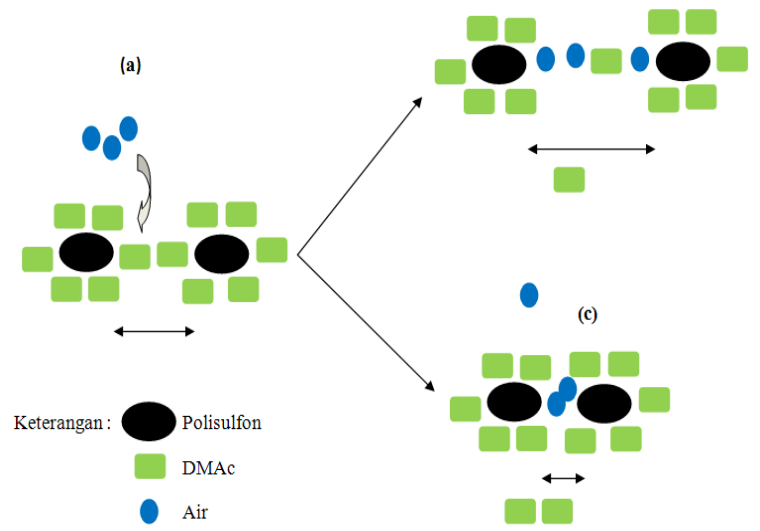

Gambar 5. Difusi Mekanisme difusi antara air dan DMAc pada membran polisulfon-lempung

\section{KESIMPULAN}

1. Media koagulasi yang digunakan dalam pembentukan membran hibrid polisulfonlempung (PEL A dan PEL B) mempengaruhi derajat kristalinitas dari membran yang dihasilkan.

2. Membran PEL A yang menggunakan koagulan air mempunyai derajat kristalinitas 63,1185\% dan membran B yang menggunakan koagulan campuran 2propanol-air mempunyai derajat kristalinitas 31,7691\%.

3. Koefisien difusi non pelarut air yang lebih tinggi dibandingkan non pelarut campuran 2-propanol-air menyebabkan pertukaran antara pelarut (DMAC) dan non pelarut air lebih cepat dibandingkan non pelarut campuran 2-propanol-air yang menghasilkan struktur kristal yang lebih teratu.
4. Kekuatan ikatan hidrogen antara molekul 2-propanol-air pada gugus sulfon dan alkoksi lebih lemah dibandingkan ikatan hidrogen dengan non pelarut. air menyebabkan derajat kristalinitas membran hibrid polisulfon-lempung PEL B lebih rendah dibandingkan membran PEL A yang menggunakan air sebagai non pelarut

\section{DAFTAR PUSTAKA}

Cifriadi, A. Holil, B \& Riyadi, M.A., 2005, Karakteristik Film Polisulfon Sebagai Bahan Dielektrik Sensor Kelembaban Jenis Kapasitif, Jurnal Sains Materi Indonesia 6 (3):61 - 65 .

Dann S.E., 2000, Reaction and Characterization of Solid, UK: The Royal Society of Chemistry.

Kohan, M. 1973. Nylon Plastics. John Wiley and Sons, New York.

Rabek, FJ., 1980, Experimental Methode in Polymer Chemistry, John Willey and Sons, New York.

Tweddle, T.A. Striez C.N \& Kutowy O.,1994, Laboratory Workshop, Membrane Fabrication and Membrane Testing, CIDA Course, Canada

Young, T. H \& Leo, W.C.,1996, Pore Formation Mechanism of Membranes from Phase Inversion Process, Desalination 103: 233 247.

Young, T.H. Chih, C.H. Li, Y.C \& Yen, S.H., 1999, The Formation Mechanism of Membranes Prepared from The Crystalline EVAL Polymer-Water-(Nonsolvent)-2Propanol (Nonsolvent) System. Journal of Membrane Science. 159: 21 - 22. 